\title{
Can Euro Zone Survive and Long Prosper?
}

\author{
Dapontas Dimitrios \\ Technological Institute of Ionian Islands Zakynthos, Greece \\ dimisdapont@gmail.com
}

\begin{abstract}
The current problems on the aftermath of the global credit crunch left the weakest Euro countries in the turbulence of a debt crisis, which has been spread in five countries (Greece, Ireland, Portugal, Italy and Spain respectively) and raised the question of a Euro zone future survival. The surviving barriers have to do with limitations and restrictions on the single market, the lack of political union and different monetary policy targets. Incentives to secede are also present. However, a possible withdraw of a country would have high cost for all the participants and it could lead to monetary union's demolition. The costs related with a possible withdraw are high, thus it is difficult for a country to leave a union. In the recent debt crisis, the countries accepted bailouts from their counterparts and international organizations in order to prevent the Euro zone collapse spreading the crisis further. Three possible Euro zone future scenarios are analyzed. The volunteer or not breakup of the union and reintroducing of national currencies, the breakup of the Euro zone to two currencies consisting Optimal Currency Areas (OCAs)is analyzed by using thirteen equally weighted optimum area criteria and the imposition of an interest equalization tax(IET) in order to make the Euro zone a single OCA. The results show that the asymmetries lead to the crisis persists in a possible two Euros area and this scenario cost is higher than union dissolution's. An IET can help Euro zone in the short time to develop sustainable characteristics.
\end{abstract}

Keywords: Asymmetries, OCA, monetary policy, interest equalization tax, dissolution

\section{Introduction}

The current debt crisis in the Euro zone has made clear that the current form of EMU is far from being an Optimal Currency Area (OCA). Possible national market problems transferred through financial contagion channels to other countries as asymmetric shocks. The economic development is also asymmetric. Countries, which share the same currency, have different economic, social, political and legal framework, but they have to share the same monetary policy. The countries had also the obligation to bailout their weaker counterparts acting as lenders of last resort for them in order to maintain the union increasing their exposure to the initial financial infection. The loss of economic independence, the asymmetric shocks through contagion and the bailout obligation are the major disadvantages of EMU participation (Cohen, 2003). The current scheme cannot last for long. There is no withdraw process and if a country capable of forming an independent monetary policy abandon the union or bankrupt the other countries will (or they should) lead union to dissolution because the costs related to the maintenance of a broken monetary scheme are high(Blanchard, 2006). The dissolution (1stscenario) is presented along with a set of two sustainability scenarios. After analyzing the characteristics of a possible OCA, I am presenting a set of 13 variables to make quantification on each country's characteristics. I present the voluntarily breakup of the union in two new free floating currencies consisting of countries having common characteristics $\left(2^{\text {nd }}\right.$ scenario) and a third scenario involving the impose of an interest equation tax along with reforms could make the Euro zone an OCA. The paper is structured as following: The next part is presenting the disadvantages of European monetary union. The third part provides the dissolution scenario. OCA requisitions, the relative data set and scenarios on the forth part. On the final section, I conclude based on data results criticizing the three scenarios and I propose incentives on possible further research.

Monetary union's problems and disadvantages: When the common European currency introduced back in 1999, the monetary union plausible advantages were overestimated while potential disadvantages were put aside. Since 1999, progress has been made. Intra-trade within EU has been stimulated because of the non-tariff and single market policy. Factor mobility has also been increased despite the limitations put by older members to their newer counterparts (countries accessed union after 2003). The price transparency is another advantage linked to the common currency creating benefits for business and consumers. Transaction costs, which can appear in different ways (commissions and buying and selling prices spreads), eliminated within the zone (De Grauwe and Moesen, 2009). Despite its obvious advantages, Euro zone is debated for its disadvantages. Some of them have been known and 
expected since its foundation. Despite early literature (Gros and Thygesen, 1998) and (Pszezolka, 2004) which emphasized on temporary negative effect of transaction costs, this problem seems to be less important than the others are. The most interesting fact has to do with disadvantages, which were not expected on their current extension. The problems are so severe nowadays leaving the existence of Euro zone under question (Masson, 2011).

The major expected disadvantage is the loss of monetary autonomy and national macroeconomic policy autonomy. The introduction of a common central bank, which handles the interest rate of Euro along with the single currency without capital, controls. Countries cannot determine their own monetary policy and inflation rate. The trade-off between unemployment and inflation is unable. The countries have to put their inflation in to the line with the lower inflation rate. Regional disparities are also present. Some union countries gain while others lose. Regional policies have fallen out of favor because of the political manipulation, economic adjustments delay and insufficient industries funding. Finally, the exchange policy instrument was also lost, this loss would not matter if they had only fiscal policy but the problem of external balance is also present. Whether the zone could have a balanced external trade, they experienced countries having surpluses and others having deficits (De Grauwe, 2003). The debt crisis showed the disadvantages of the monetary union which they were not projected. Asymmetric shocks which had to be avoided for the counties of the monetary union were present because some countries were infected in the first stage of crisis (PIG debt problem) and within the union the problem amplified by contagion exposing initially not infected countries to credit risk transforming crisis to symmetric within the zone.(Costa and Mota, 2011) Another unpredicted disadvantage has to do with the role of internal "lender of last resort" which countries were called to play recently.

Countries having better economic results are forced from their political decision of bailing out weaker economies exposing themselves to other countries credit risk doubting whether they would receive their loans on the maturity dates or not. The lack of central policy or in other words political union among the European countries was a problem recognized even before the EMU creation (Schinasi and Texeira, 2006). The Europeans hoped that the monetary union would lead to an extended political bonds creation. However, individual economic policies acts were actions against the mutual monetary policy. The Euro group where the political decisions related to Euro are unofficially but substantially taken, lost its confidence among the European citizens of being capable to plan and imply strong monetary policy. A future risk has to do with their exposure to weaker countries default. If a country within the zone cannot meet its repayments its lenders and reintroducing a national currency, they will lose their funds and they will be forced to introduce immediately national currencies to avoid part of the dissolution later costs. As shown, the disadvantages from the current scheme are many and difficult to solve. With its current form, EMU cannot last for long. In the next part we are about to see the dissolution scenario where a country is selecting to introduce a national currency in order to gain from a possible autonomous monetary policy, the effect of its decision to the other monetary union countries and the effects on their monetary policy change (Robichaud, 2011).

\section{Euro zone dissolution scenario}

A monetary union has never been made to be broken. However, under unlucky political or economic circumstances none of the modern monetary unions has remained untouched and only microstates bonded to larger neighbor's currency monetary union and the CFA zone are still in operation for more than 50 years. The reason behind the long-term existence has to do with the high cost of independent monetary policy. If a country cannot afford it could leave its monetary policy guided by the larger country or the union common central bank. It would order to find the reasons of breakup excluding the cases of previous political disintegration (Former USSR, Yugoslavia and Czechoslovakia respectively) (Fidrmuc and Horvath, 1998) bonding or dollarization (many cases in Central and South America). In our case, though we can presume that this dissolution scenario refers to the voluntary participation unions such as Euro zone. With exception of high political risk, incentives to secede are developed because of inefficiencies due to integration. A country in order to leave the EMU will face a large depreciation of its currency followed by exports decline, transition costs and political and economic risk rise. (Blanchard, 2006) However, it will leave if its cost of national currency reintroduction is lower than the maintained cost of being a part of a monetary union in the long term.

Leaving a monetary zone cannot be a single side decision and unions do not have a smooth and volunteer leaving process by their creation, only temporary solutions can be proposed. (Fuchs and Lippi, 2005) We 
exclude the parallel circulation of both national and common currency, which cannot last for long due to Gresham's law ${ }^{1}$ (Mundell, 1988). On the other hand, we propose three plausible scenarios: the voluntarily withdraw of a country from the union, the dissolution and the reintroducing of national currencies. The remaining countries to the zone will also have strong incentives to leave the zone immediately because there is a possibility to avoid the majority of the high broken zone maintenance cost and gain from the strong motive of autonomous monetary policy profits. The point where a monetary union dissolute is also an important issue. When a country leaves a scheme if its size can work as a monetary policy individual the scheme breaks down. Comparisons cannot be made between EMU and Latin Monetary Union, which can be considered more as a fixed rates club. There was not common currency and one central bank. Monetary discipline was also absent. Thus there was no single currency or central bank for a long time to abandon and the members' commitment was loose the consequences from the national currencies mint didn't have negative effects on members economies (Bae and Bailey,2011). The possible devaluation long-term positive effects in competitiveness are the major motive that the breaking country has to leave the monetary union. The reintroducing national currency costs are high and a possible decision has to be taken by monetary authorities is analyzed in various categories of cost acting as barriers for a possible exit (Fuchs and Lippi, 2005).

An initial effect of the reintroducing announcement is the rise of risk and interest rates on countries' debt, not only for the abandoning country but also for the whole zone. This is a penalty for the leaving country, but also for the others that let the union broke. Credit ratings will lower increasing the pressure on the now independent central bank to raise interest rates and further devaluation. Internal economic problems also occur. To regain its competitiveness a country should reduce, according to an earlier work (Blanchard, 2006) referring to the case of Portugal as a possible leaving country, a $25 \%$ wage reduction as to be made. Further reduction to the wages will follow possible trade flows from abroad. Because of its inconvenience, due to unfair manipulating monetary issues failing to maintain the previous commitment of monetary union will imply a tariff to their exports to the breaking country. In order to maintain its competitiveness country must transfer this tariff to its workers as a wage reduction. This compensatory tariff can be also followed by unfair monetary exchange rate policy to attract FDI or restrictions to their citizen's freedom. Political disintegration is another major consequence of the economic and monetary independence. An abandoning country, something that is no provision in the European Union, obviously did not estimate the profits from the political integration. The other members will not easy participate to discussions for common foreign policy and a European Army creation.

Through this process, weaker countries are excluded from the European Union decisions and in a later stage from the Union itself. This would have also a major effect on their international trade position against these countries and the European Union because all participants will lose EU membership and its benefits. This will lead to higher country risk ad interest cost. Reintroducing new currency also involves technical and legal obstacles. Some of those are associated with the initial competitiveness depreciation itself. In order to be effective the currency introduction should be followed by debt and savings redenomination inside the country otherwise it will lead to financial distress and bankruptcies. All money working equipment (ATMs, Payment machines, airport handlers etc.) must be reprogrammed; notes and coins have to be minted and placed all over the country. A short period of double circulation is also important for the smoothest possible transition, raising further costs. In any case more measures will be needed to keep people from massive withdraws, and bank runs to foreign banks. A "corralito" limit to bank withdrawals can be an immediate remedy but it cannot be a long-term measure. The bond issues cannot be easy accepted by international markets having a junk rating status and interest rates will rise further. Redenomination of the foreign debt is also plausible out of favor of the positioned investors who will have great loss of the country's inconvenience. If they suit the country in the European court of justice, they will receive remedy because the court will not be favor against braking country.

The other members will have to pay the increased cost occurred by the country's retirement. Unless their action is coordinated and rapid they will have to pay a short-term cost, which is $50 \%$ devaluation and further devaluation in the long term, the possible share of the leaving country to the ECB, the possible bailouts given will be under question and the loss from the possible independent monetary policy. If the remaining countries coordinate their action, of introducing national currencies, they will keep their political sustainability keeping their competitiveness and wages level and they will not have to bail out their joint central bank. Markets will be probably positive in a possible common action looking to the

\footnotetext{
"'Bad money drives out good if their exchange rate is set by law".
} 
future of the countries. People are also favorite to their national currencies and the political decision may be easier. The sunk cost, which cannot be avoided in any case, consists of the credit risk lowering costs compared to the zone maintenance and the loss of debt repayments plus technical cost (Boonstra, 2010). In any case, this scenario seems to have large cost for all the countries but the cost for the leaving country will be unbearable. In real life, a country will not easy let voluntarily the union to dissolute and the others will decide to abandon the union when the exposure to possible delayed or lost debt repayments will be already high.

\section{OCA scenarios}

Making Euro zone an OCA in the long term has been the ultimate goal since its foundation. Possible multiple breakup to a set of more than one OCAs (Tootel1990) could be more operative and effective. A more realistic target is the implement of a common interest system allowing countries to participate in the financial markets equally with the implementation of an interest equalization tax within the zone as a presumption of the short term effective monetary policy along with specific and customized in each country's needs to eliminate regional disparities transforming zone to an OCA. These scenarios of multiple OCAs and interest equalization tax implementation are analyzed in the present sector. In a similar work (Monga, 1997) author listed 19 relevant criteria for a successful currency union in Francophone Africa. The level of freedom in certain sectors of the economy is crucial for creating or maintaining monetary unions. More freedom means larger flexibility for the referring country making it keen to accept needed transformations to be a part of an OCA. The OCA countries levels have to be equal. I made transformations to the original variables in order to transform them to meet my current research criteria. I have deployed the latest (2011) dataset from Heritage foundation for economic freedom scores(Business, Trade, Fiscal, Government spending, monetary, investment, fiscal, property rights, Freedom from corruption and labor freedom) ${ }^{2}$, political risk from Euro money country and political risk rate and credit rating from international agencies respectively consisting an 13 variables dataset. In (Monga, 1997) the measure is ordinal and based on estimates. Integer values range from two (heavy disadvantage or incentive) to +2 (strong advantage) using zero (0) if the effect is neutral. The variables have the same weight and added to make a final index.

In contrast to the referred one (Monga, 1997) I used quantities data provided by referred sources using as population the specific scores for each series calculating its average and standard deviation. The methodology choice has to do with the fact that asymmetries are present. Use these descriptive measures to give each country a score for each variable. The higher deviation means higher asymmetry. Thus, the effective grouping to two has to be made based on higher asymmetries of the population average. The constructing of the indices is following the deviation ordination pattern. If the value is smaller than one standard deviation from the mean I note it as a heavy disadvantage (-2), from one standard deviation to mean (not included) is a minus one ( -1$)$, from mean to one standard deviation (not included) variable is a plus one (+1) and finally if the value is more than one standard deviation it takes a plus two (+2). I omitted zero because the countries are already in a union and none of this effects can be taken as neutral for them. The weights are still equal. Countries with positive final index can be counted as possible candidates for an OCA scheme and negative final index means that the country has to make possible transformations in order to improve its score or its candidate to format another OCA with other low final index countries. The results are shown on the following table.

Cyprus, Estonia, Finland, France, Germany, Ireland, Luxemburg and Netherlands) have positive final index showing that their scores are close and are primary candidates for an OCA. The levels of freedom and development seem to be similar and positive. The other seven countries have negative score in the index (Greece, Italy, Malta, Portugal, Slovak Republic, Slovenia and Spain) which means that they cannot be members of an OCA with their current scores and have to make major transformations to join a common currency area, which can be named optimal. In a possible, multiple currency areas scenario these two groups seem to consist the initial group of the two new Euros. A "hard" one based on positive score countries and a "soft" one based on negative score countries. Possible advantages of this scheme *can be identified. The control of the monetary policy is more flexible for a participating country than the larger union (De Grauwe, 2003). Political cost seems to be lower than the dissolution's scenario. (Blanchard, 2006), (Fuchs and Lippi, 2005). The regional asymmetries are expected to be smaller because countries

\footnotetext{
${ }^{2}$ Variables methodology and analysis can be found on Heritage foundation index of economic freedom (2011) Appendix.
} 
scores and characteristics are closer. The markets will be easier to accept this division and transition costs will be lower.

Table 1: OCA indexes for all countries union, the results show that 10 countries (Austria, Belgium,

\begin{tabular}{|c|c|c|c|c|c|c|c|c|c|c|c|c|c|c|c|c|c|}
\hline 효료 & 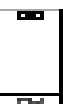 & 早 & $m$ & $m$ & 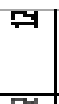 & 4 & $n$ & 7 & $n$ & +1 & 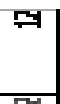 & 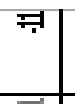 & 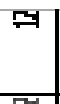 & 9 & 4 & sp & 7 \\
\hline 蕞 & $y$ & $\Rightarrow$ & 7 & 7 & $\sqrt{74}$ & 74 & $\sqrt{7}$ & 7 & $\because$ & $\overrightarrow{7}$ & $\pi$ & $\vec{\theta}$ & & $\overrightarrow{7}$ & $\overrightarrow{7}$ & $\overrightarrow{7}$ & $\overrightarrow{7}$ \\
\hline 복 & & $\Rightarrow$ & $\Rightarrow$ & $\Rightarrow$ & 74 & $\Rightarrow$ & $\Rightarrow$ & 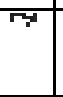 & $\Rightarrow$ & $\overrightarrow{7}$ & $\sqrt{-4}$ & $\vec{\theta}$ & $\Rightarrow$ & 7 & $\vec{\theta}$ & $\Rightarrow$ & $\overrightarrow{7}$ \\
\hline 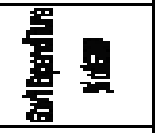 & "ד & $r$ & $\rightarrow$ & 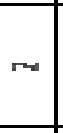 & $r$ & $x$ & $\rightarrow$ & $\pi$ & $\rightarrow$ & " & 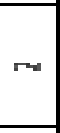 & $\pi$ & " & "T & 70 & $\rightarrow$ & $\rightarrow$ \\
\hline 量畐 & 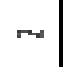 & 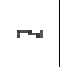 & 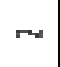 & $\rightarrow$ & 7 & $\Rightarrow$ & 7 & $\vec{P}$ & 74 & $\because$ & $\because$ & $\rightarrow$ & $\rightarrow$ & 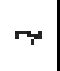 & $\rightarrow$ & 7 & $\vec{r}$ \\
\hline 吾章 & $\rightarrow$ & $\rightarrow$ & $\vec{\theta}$ & $\because$ & 7 & $\rightarrow$ & $\rightarrow$ & 7 & $\rightarrow$ & 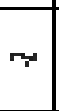 & $\rightarrow$ & 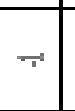 & 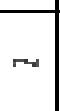 & 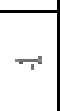 & 7 & 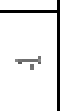 & $\rightarrow$ \\
\hline 雪 촌 & 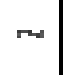 & $\rightarrow$ & $\rightarrow$ & $\rightarrow$ & 74 & $\rightarrow$ & 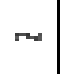 & $x$ & 7 & $x$ & 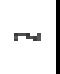 & $\pi$ & $\rightarrow$ & " & $x$ & $\infty$ & $r$ \\
\hline 胥墥 & $\rightarrow$ & $\rightarrow$ & $\rightarrow$ & 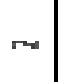 & 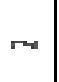 & $\rightarrow$ & $\pi$ & $\pi$ & $\rightarrow$ & "ד & $\pi$ & 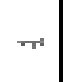 & 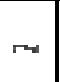 & 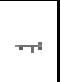 & $\rightarrow$ & $\infty$ & $n$ \\
\hline 恿盍 & $\rightarrow$ & $\rightarrow$ & $\overrightarrow{0}$ & 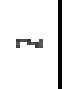 & $\rightarrow$ & 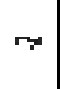 & $\rightarrow$ & 7 & 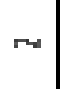 & 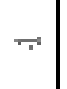 & 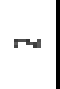 & $\overrightarrow{0}$ & 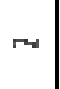 & 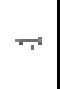 & $\overrightarrow{0}$ & 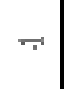 & - \\
\hline 勇 & $\rightarrow$ & $\rightarrow$ & 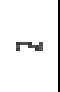 & $x$ & ${ }^{\circ}$ & $\rightarrow$ & $\rightarrow$ & $\pi$ & 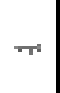 & $\rightarrow$ & $\rightarrow$ & $x$ & $\rightarrow$ & $\rightarrow$ & $\pi$ & $\pi$ & - \\
\hline 矛 莗 & $\rightarrow$ & $\because$ & 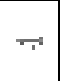 & 7 & 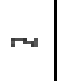 & 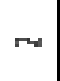 & $\rightarrow$ & 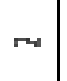 & $\because$ & $\rightarrow$ & 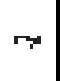 & 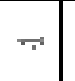 & $\rightarrow$ & $m$ & $r$ & 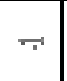 & $\vec{r}$ \\
\hline 理 吾 & 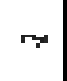 & קי & $r$ & -4 & $\rightarrow$ & 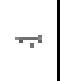 & 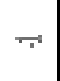 & $\rightarrow$ & $\rightarrow$ & 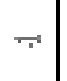 & $\rightarrow$ & 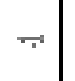 & 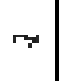 & 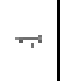 & 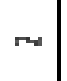 & $\rightarrow$ & $\vec{r}$ \\
\hline 固吾 & $\rightarrow$ & $\rightarrow$ & 7 & $\rightarrow$ & $\rightarrow$ & 7 & $\rightarrow$ & 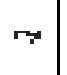 & $\rightarrow$ & $\rightarrow$ & $\rightarrow$ & $\rightarrow$ & $\rightarrow$ & $\rightarrow$ & $\rightarrow$ & $\rightarrow$ & $\rightarrow$ \\
\hline 青氞 & $r$ & 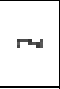 & 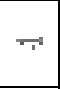 & 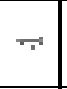 & 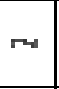 & $\rightarrow$ & $\pi$ & $\because$ & 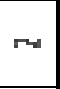 & 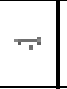 & $\because$ & 7 & $\rightarrow$ & 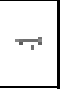 & 7 & $\rightarrow$ & $\vec{r}$ \\
\hline & 蜀 & 童 & 봉 & 囬 & 疍 & 焉 & 誓 & 㴓 & 量 & 䙵 & 翌 & 侄 & 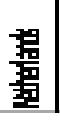 & 費 & 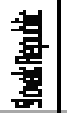 & 罡 & 潼 \\
\hline
\end{tabular}

The creation of multiple currency areas in the euro case has to fulfill some fundamental presumptions. Initially the countries consisting a new monetary zone must accept that the two currencies will free float between them. Otherwise, the scheme substantially does not change and its problems remain. Additionally there is no OCA if the participating countries don't share the same borders because the trade volume isn't so high among the zone countries. In current scenario Cyprus and Slovak republic don't border with the other participants and they have to be excluded facing the cost of an abandoning country facing a major disadvantage for the scenario The results of the 9 countries "Hard Euro" and 6 countries "Soft Euro" are shown below:

As we can see, the asymmetries were smoothened but they did not eliminate. In the "Hard Euro" France, Belgium and Estonia and in the "Soft Euro" Greece, Italy and Portugal seem to be week indicating a negative score. The problems didn't solve and in fact the dissolution of the common currency to a set new of Euros and future national currencies introduction is still extremely plausible and the total cost of this scenario is larger compared to national currencies introduction because the initial split had significant cost which is comparable to the additional total dissolution cost. Nowadays there is a debate for the issue of a possible Eurobond as a solution for the current debt crisis. The fact is that Euro zone markets become less liquid because of the "flight to safety" syndrome or they reflect a default risk. There are many disadvantages making this solution impossible. The main issue has to do with the free riding problem 
caused by high spread countries being less motivated to imply sustainable fiscal policies. The participation to a joint bond evolves major moral hazard is pressuring from the implicit insurance from this issue.

Table 2: "Hard "Euro scenario

\begin{tabular}{|c|c|c|c|c|c|c|c|c|c|c|c|c|c|c|}
\hline & & & & & & & & & & & & & & \\
\hline & $\mid$ & 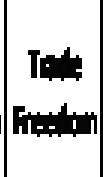 & $\left|\begin{array}{l|}\mid \\
\mid\end{array}\right|$ & 的 & 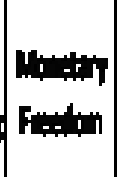 & 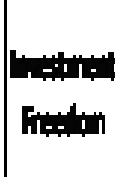 & $\left|\begin{array}{|l|l|l|}\mid \\
\mid\end{array}\right|$ & 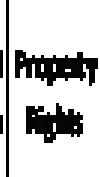 & | & 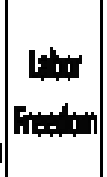 & Ext & 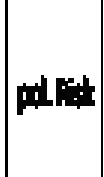 & 要 & لباب \\
\hline Astí & 2 & 1 & -1 & -1 & 1 & -1 & -1 & 1 & 1 & 2 & -1 & & & \\
\hline mi: & 1 & 1 & 2 & -1 & 1 & 1 & -1 & 2 & -1 & 1 & -1 & 1 & 1 & 7 \\
\hline Etai் & -1 & 1 & 2 & 2 & 2 & 1 & 1 & 2 & 2 & -1 & 2 & 2 & 2 & 3 \\
\hline Fithend & 2 & 1 & 1 & -1 & -1 & 1 & 1 & 1 & 2 & 2 & -1 & 4 & 4 & 6 \\
\hline firme & 1 & -2 & -1 & 2 & 2 & 3 & -1 & -1 & 2 & -1 & 2 & -1 & 1 & -11 \\
\hline GिIादा & 1 & 1 & -1 & 1 & 2 & 1 & -2 & 1 & 1 & 2 & 1 & 1 & 1 & 6 \\
\hline Ltand & 1 & 1 & 1 & 1 & -1 & 1 & 2 & 1 & 1 & 2 & 1 & 2 & 2 & 3 \\
\hline Luentbars & 2 & 1 & 1 & 2 & -1 & 1 & 1 & 1 & 1 & -1 & 2 & 2 & & 9 \\
\hline Weltaltent & -1 & 1 & -1 & -1 & 1 & 1 & 1 & 1 & 2 & 1 & -1 & 1 & 1 & 6 \\
\hline
\end{tabular}

Table 3: 'Soft" Euro scenario

\begin{tabular}{|c|c|c|c|c|c|c|c|c|c|c|c|c|}
\hline Country & $\begin{array}{l}\text { Business } \\
\text { Frecedom }\end{array}$ & $\begin{array}{c}\text { Trade } \\
\text { Freedom }\end{array}$ & $\begin{array}{l}\text { Fiscal } \\
\text { Freedom }\end{array}$ & $\begin{array}{c}\text { Gor't } \\
\text { Spending }\end{array}$ & $\begin{array}{l}\text { Monetary } \\
\text { Freedom }\end{array}$ & $\begin{array}{l}\text { Investiment } \\
\text { Freetom }\end{array}$ & $\begin{array}{l}\text { Financial } \\
\text { Freetom }\end{array}$ & $\begin{array}{l}\text { Propetty } \\
\text { Rights }\end{array}$ & $\begin{array}{c}\text { Labor } \\
\text { Freedom }\end{array}$ & pol, Risk & $\begin{array}{l}\text { cteditit } \\
\text { rating }\end{array}$ & Final lindax \\
\hline Greece & -1 & -2 & 2 & -1 & -1 & -2 & -1 & -2 & 1 & -2 & -2 & -10 \\
\hline Italy & -1 & 1 & -2 & -2 & 1 & 1 & -1 & -2 & -1 & -1 & -1 & .7 \\
\hline Malta & -2 & 1 & 1 & 1 & -2 & 1 & -1 & 1 & 2 & 1 & 1 & 5 \\
\hline Portugal & 1 & 1 & -1 & -1 & 2 & -1 & -1 & 1 & -2 & -1 & 1 & -2 \\
\hline \$lowęnia & 2 & 1 & 1 & 1 & -1 & -1 & -2 & -1 & -1 & 2 & 1 & 0 \\
\hline Spain & -1 & 1 & -1 & 2 & 2 & 2 & 2 & 1 & 1 & 1 & 2 & 13 \\
\hline
\end{tabular}

Countries with triple A is rating will lose their borrowing advantage and they have to fund their debt with higher interest. There is also a set of practical problems. The share of collective responsibilities has to be done, but under what scheme of weights. If the weight in the yield is different from the weight, on the Euro, main liquidity problems arise and the proposed fund will have to cover these asymmetries. In recent works (De Grauwe and Moesen 2009) and (De Grauwe, 2011) recognize these problems and they suggest major changes on the joint plan. First, they propose that share on bond should be connected to the country's equity shares on joint for 60 per cent of its GDP (blue bonds) and from the markets and the rest from national bond markets (red bonds) in higher prices. This plan can be easily recognized by speculators and the issue amount is limited exposed to a coordinated attack. They also suggest different fees for the countries' blue bonds. The same problem will rise instantly and the asymmetries will be amplified when the attack will be specialized to the weaker countries. Finally, they propose that each government will pay the interest on its part of the bond on yearly basis. However, what will happen if one or more countries cannot pay their shares? They will probably ask for further lending within the Euro zone.

The coordination of monetary policy can be achieved using an interest equalization tax stabilizer (IETS) first introduced by (Benavie and Froyen, 1992). They name the monetary policy along with an interest equalization tax can be more effective than monetary policy alone. Ineffectiveness within EMU can be smoothened within the union. Each country participating in the monetary union pays the part of the interest, which exceeds the lowest rate within the union weighted to its participation to Euro. The 
payment is done on the maturity and it will be repaid in the very long-term period ( 25 years or more). This measure is temporary and it can be implied until the current debt crisis is resolved and the necessary reforms to the weaker countries are made in order to reach the target of an OCA. The countries are funded through the market and not through stability facilities such as proposed EFSF. Lending cost is reduced for the weaker countries compared to the "lender of last resort" solution. The stronger countries will not lose their credit rating and they will not increase their lending rates. The zone will sustain in the short term as long as the mechanism works and the fundamentals for a tighter union are present. This scenario is the easiest and fastest on its implication. A major disadvantage has to do with the will of the stronger countries to fund this mechanism and for how long. However, if they consider it as zone sustainability, sunk cost is preferable to the opportunity cost of a possible dissolution. The other disadvantage has to do with the time of implication, which has to be short and strictly connected to the market liberation transitions- balanced fiscal policy path. The political decision of funding this possible solution has to do with the existence of the European Union itself.

\section{Conclusions and further research proposal}

The present work has presented three possible scenarios related to transformations for the EMU future. Present debt crisis is testing the durability and long prosperity of the European Union itself. Being on the decision dead-end under this pressure as a motive for reform and crucial decisions having to been made in order to maintain Euro zone as a monetary Union. The dissolution or breakup cost seems to be extremely high for all the participating countries and the problems does not seem to be solved by a breakup into two monetary unions, where split is based on level of economic freedom or development itself. The asymmetries seem to persist within the new smaller area which is the worst cost case scenario hiding a possible future dissolution of the smaller unions cost. The first decision that it has to be made is an opportunity cost choice. Are countries willing to pay the cost of possible dissolution or EU or they prefer the cost of an EMU maintenance? In my analysis, the second solution seems easier and preferable. Political decisions related to liberation reforms and transformations and the change of the economic environment seem to be critical for the long-term sustainability but the time for the implication of a tighter union under the present turbulence seems to be inadequate. An interest equalization tax despite its cost seems to extend the life expectancy of the union. Any Eurobond solution seems vulnerable and easy detectable by speculators. In a future work, the time of EMU transforming to OCA or in other words the short-term IETS maintenance time and proposed cost can be calculated. This is a sort introduction to possible future solutions for the future of the Euro zone. Opening the present discussion can be a step further for more efficient economic and political decision-making.

\section{References}

Bae, K. H. \& Bailey, W. (2011). The Latin monetary union. Some evidence on Europe's failed common currency. Review of development finance, 1, 131-149.

Benavie, A. \& Froyen, R. (1992).Optimal monetary policy with an interest equalization tax. Journal of Macroeconomics, 14(3), 449-466.

Blanchard, 0. (2006). An adjustment within the Euro: The difficult case of Portugal. Unpublished manuscript, MIT, Boston.

Boonstra, W. (2010). Breaking up the Euro: Blessing or disaster. Rabobank economic research department working papers. Netherlands.

Cohen, B. (1993).Beyond EMU: "The problem of sustainability", Basil Blackwell Ltd., Cambridge MA.

Cohen, B. (2003). Are monetary unions inevitable? International Studies perspectives, 4, 275-292.

Costa, F. A. \& Mota, P. (2011). The roots of the Euro zone sovereign crisis: PIGS vs Non. PIGS. Panoeconomicus, 5,631-649.

De Grauwe, P. (2003). Economics of monetary union. $7^{\text {th }}$ edition.Oxford press.

De Grauwe, P. (2011). Joint issue of Eurobonds. CESifo Forum 2/2011.

De Grauwe, P. \& Moesen, W. (2009). Gains for all: A proposal for a common Euro bond. Inter Economics University of Leuven, May /June.

Fidrmuc, J. \& Horvath, J. (1998). Stability of monetary unions: lessons from the breakup of Czechoslovakia. Netherlands organization of scientific research.

Fuchs, W. \& Lippi, F. (2005). Monetary union with voluntary participation. Stanford Institute for economic research. Stanford University.

Georgioni, G. \& Holden, K. (2000). The crisis of the CFA Franc zone. Working paper, Economic modeling.

Gros, D. \& Thygesen, N. (1998). European monetary integration. $2^{\text {nd }}$ edition Longman. 
Heritage Foundation. (2010). Index of economic freedom 2011. The Heritage Foundation, Washington DC. Krugman, P. \& Obstfeld, M. (2011). International economics, theory and policy. $9^{\text {th }}$ edition, Prentice Hall, Boston.

Masson, P. (2011). Fiscal asymmetries and the survival of the Euro zone. The Centre for governance innovation, 1, 1-23.

Monga, C. (1997). A currency reform index for Western and Central Africa. The world economy, Blackwell publisher's ltd., 103-125.

Mundell, R. (1988). Uses and Abuses of Gresham's Law. In the History of Money, Columbia University.

Pszezolka, I. (2004). Advantages and disadvantages of Introducing Euro. Working paper.

Schinasi, G. \& Texeira, P. (2006). The lender of last resort in the European single financial market. IMF working paper.IMF.

Robichaud, F. (2011). Lender of last resort in the Euro zone. Who will stand up and do the job? Central European university department of political science, Budapest Hungary.

Tootel, G. (1990). Central bank flexibility and the drawbacks to currency unification. New England Economic review, 2, 3-18. 